\title{
Relationship between Population Dynamics of Pseudomonas cichorii on Lettuce and Disease Incidence of Bacterial Rot of Lettuce
}

\author{
Yasufumi HIKICHI*, Akira SAITO* and Kazumi SuZUKI*
}

\begin{abstract}
Leaves of lettuce (Lactuca sativa L. cultivar Success) were dipped in a solution of Pseudomonas cichorii. Population of $P$. cichorii on leaves incubated at $30^{\circ} \mathrm{C}$ was $1.3 \times 10^{8} \mathrm{cfu} / \mathrm{g}$ fresh weight 7 days after inoculation and disease incidence of bacterial rot of lettuce was severe. The bacterial population on leaves, which were incubated at $20^{\circ} \mathrm{C}$, was less than $10^{5} \mathrm{cfu} / \mathrm{g}$ fresh weight, and disease incidence was slight. Lettuce plants were cultivated in a field, in which many lettuce plants had been severely infected with $P$. cichorii at any year, in Ichinohe-machi, Iwate Prefecture. $P$. cichorii had been isolated at the low density from soil since 37 days before transplanting. $P$. cichorii was isolated at the low density from entire plants before head formation. The bacterial population on leaves during head formation is lognormally distributed, and bacterial rot was detected on the bulked leaves, from which $P$. cichorii was isolated at the density of above $10^{5} \mathrm{cfu} / \mathrm{g}$ fresh weight. The bacterial populations increased on outerleaves and head-leaves in the early stage and the middle stage of head formation, respectively. The bacterial population on head-leaves positively correlated with that on outer-leaves. The percentage of lettuce plants with diseased head-leaves positively correlated with that with diseased outer-leaves. Therefore, $P$. cichorii exists on leaves of lettuce during head formation as the epiphytic bacterium and disease symptom is detected on the leaf in which population of $P$. cichorii is above $10^{5} \mathrm{cfu} / \mathrm{g}$ fresh weight. $P$. cichorii, with which outer-leaves are infected, is an important infection source of the disease on head-leaves.
\end{abstract}

(Received November 14, 1995 ; Accepted February 7, 1996)

Key words: Pseudomonas cichorii, Lactuca sativa L., bacterial rot of lettuce, epiphytic bacterium.

\section{INTRODUCTION}

Bacterial rot of lettuce is one of severe diseases of lettuce in $\mathrm{Japan}^{7,8,10)}$. Causal agents of the disease are Pseudomonas cichorii, P. marginalis pv. marginalis and P. viridiflava ${ }^{7,10,11)}$. In the highlands in north and central Japan, since $P$. cichorii is mainly isolated from diseased lettuce and bacterial rot of lettuce caused by $P$. cichorii results in a great loss of lettuce, $P$. cichorii is the major causal agent of disease ${ }^{7,8,10)}$. The disease, referred to by growers as varnish spot in California and tar in Japan, is characterized by shiny, dark-brown, firm and necrotic spots that occur on leaves underneath the second or third head-leaves (Fig. 1) ${ }^{2,8,13}$. The primary infection sources seem to be seeds, infected lettuce debris, weeds and soil ${ }^{1,2,9,12-14)}$, and the bacteria have survived in soil associated with infected lettuce debris for more than three months ${ }^{1,9)}$. However, the behavior of bacteria on lettuce is still poorly understood.

This paper concerns a study on the relationship between population dynamics of $P$. cichorii on lettuce and disease incidence of bacterial rot of lettuce.

\section{MATERIALS AND METHODS}

Leaf test. Seventh leaves of lettuce (Lactuca sativa L. cultivar Success) cultivated for two months in pots were dipped in a bacterial solution of P. cichorii SPC9001, which was obtained from Mr. T. Shirakawa, Morioka Branch, National Research Institute of Vegetables, Ornamental plants and Tea, at the bacterial density of $10^{8}$ colony forming unit (cfu)/ml for $10 \mathrm{sec}$. Then leaves were incubated in plastic box at $20^{\circ} \mathrm{C}$ or $30^{\circ} \mathrm{C}$ at the humidity of $100 \%$.

Disease incidence of bacterial rot of lettuce and population of $P$. cichorii on seventy of lettuce leaves were investigated one, three, seven and ten days after inoculation (DAI). Disease incidence was estimated as follows.

Disease incidence $=100(3 A+2 B+\mathrm{C}) / 3 \times N$, where $A, B$ and $C$ are the number of diseased leaves with $>50 \%, 30-50 \%$ and $0-30 \%$ diseased area, respectively, and $N$ is the total number of leaves examined.

Ten of entire leaves sampled at random in each sampling day were weighed and were ground with a mortar and pestle in $10 \mathrm{ml}$ distilled water. The original solution and its 10 -fold serial dilutions were dispensed in $0.1 \mathrm{ml}$

\footnotetext{
* Iwate Biotechnology Research Center, Narita 22-174-4, Kitakami 024, Japan＼cjkstart岩手生物工学研究センター
} 


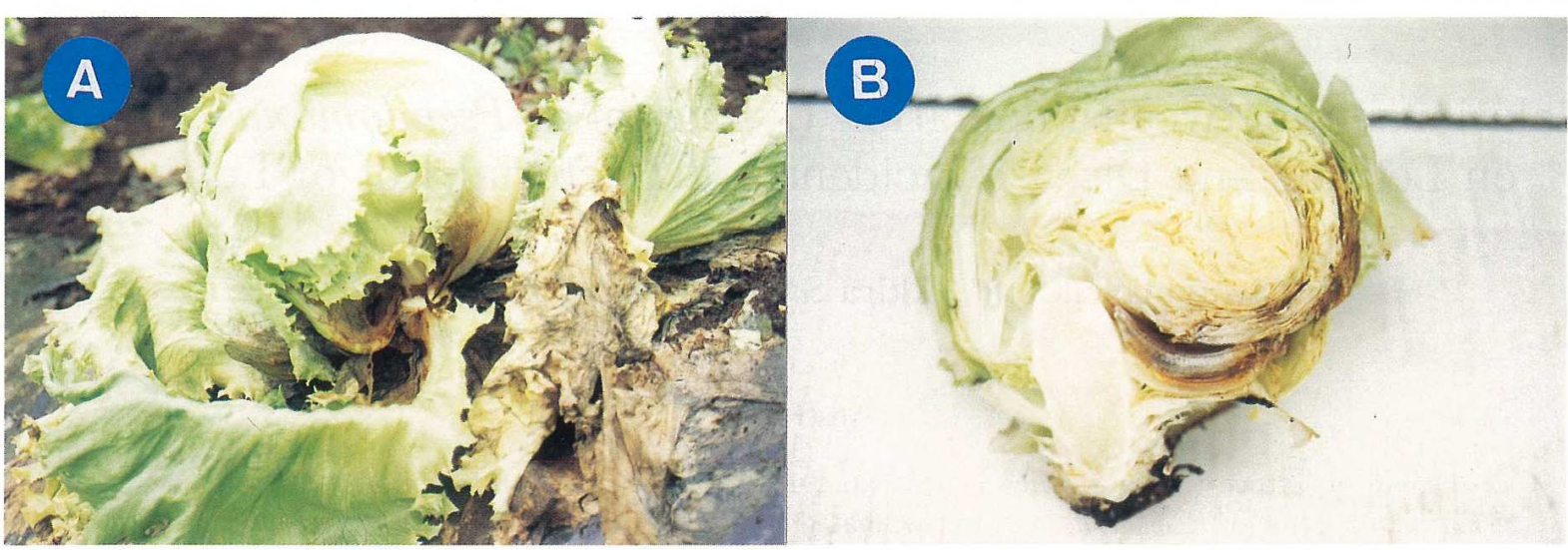

Fig. 1. Bacterial rot of lettuce caused by Pseudomonas cichorii. (A) A lettuce infected with $P$. cichorii 92 days after sowing (the harvesting time). (B) A cross section of lettuce head infected with $P$. cichorii 92 days after sowing.
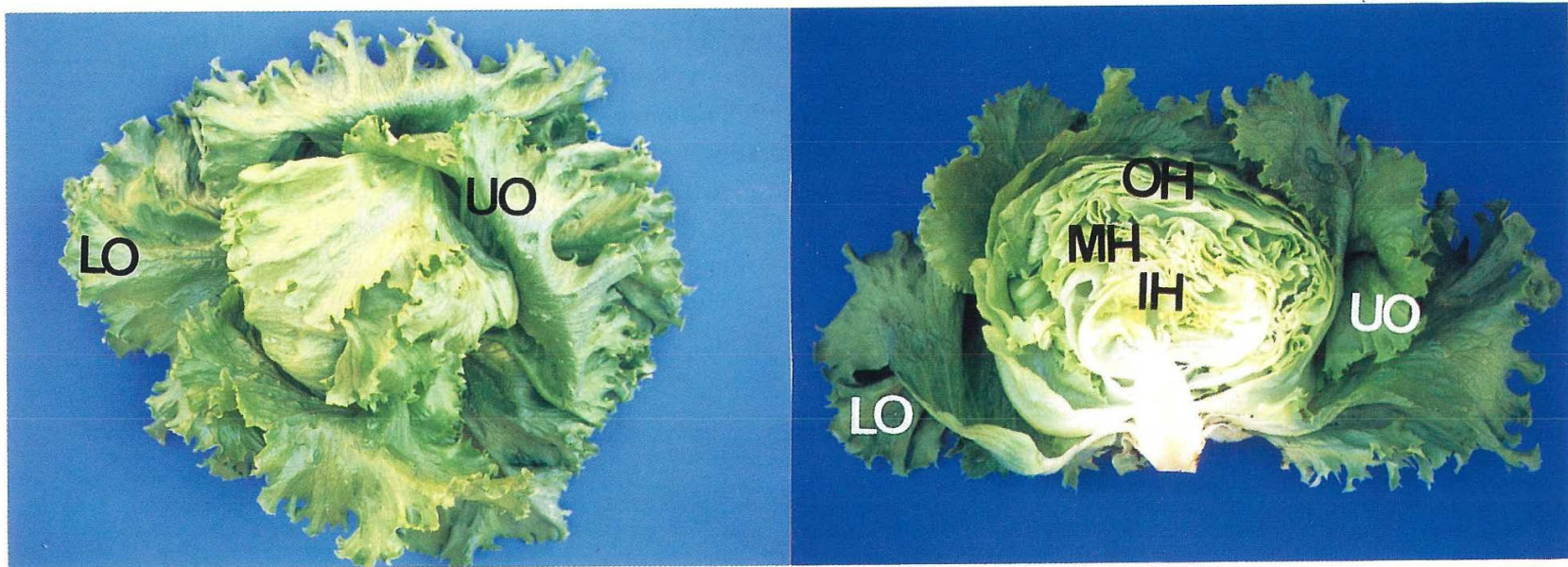

Fig. 2. Bulked leaves of lettuce sampled in the field test. LO, lower outer-leaves; UO, upper outer-leaves; OH, outer head-leaves; $\mathrm{MH}$, middle head-leaves; IH, inner head-leaves.

aliquots to three plates of the selective medium for the isolation of $P$. cichorii $(\mathrm{PCSM})^{14)}$. The plates were incubated at $30^{\circ} \mathrm{C}$ for 4 days, and counted to estimate the population of pathogen.

Field test. On July 21, 1994, two hundreds and ten of seedlings of lettuce cultivar Success 20 days after sowing were transplanted in $20 \mathrm{~m}^{2}(25 \times 0.8 \mathrm{~m})$ in Highland Cool-zone Development Center, Iwate Horticultural Experiment Station, Ichinohe-machi, Iwate Prefecture, Japan, where was located at 430 meters above the sea level. In this field, many lettuce plants had been severely infected with $P$. cichorii at any year. The head formation was first observed on August 22, and the harvesting time of crop was September 15 to 20.

The population of $P$. cichorii on lettuce plants before head formation was investigated on July 28 and August 8,12 and 22. The bacterial populations on lower outerleaves, upper outer-leaves, outer head-leaves, middle head-leaves and inner head-leaves of lettuce during head formation were investigated on August 29 and September 5, 12 and 21 (Fig. 2 and Table 1). Entire plants and leaves were weighed and were ground with a mortar and pestle in $50 \mathrm{ml}$ distilled water.
Table 1. The number of leaves of lettuce plants in the field test

\begin{tabular}{lccccc}
\hline \hline \multirow{2}{*}{ Date } & \multicolumn{5}{c}{ The number of leaves } \\
\cline { 2 - 6 } & LO* & UO & OH & MH & IH \\
\hline $8 / 29$ & 4 & 2 & 2 & 3 & 5 \\
$9 / 5$ & 5 & 3 & 3 & 4 & 9 \\
$9 / 12$ & 8 & 4 & 4 & 5 & 9 \\
$9 / 21$ & 8 & 4 & 5 & 6 & 11 \\
\hline
\end{tabular}

* LO, lower outer-leaves; UO, uppcr outer-leaves; $\mathrm{OH}$, outer head-leaves; $\mathrm{MH}$, middle head-leaves; IH, inner head-leaves.

Dew on outer-leaves sampled on the same day, were sampled with sterile filter papers at the radius of $45 \mathrm{~mm}$ (ADVANTEC TOYO, $0.6 \mathrm{~g} /$ piece) on August 29 and September 5, 12 and 21. The filter papers were weighed and were suspended in $25 \mathrm{ml}$ distilled water on a magnetic stirrer for one min.

Soil samples $(100 \mathrm{ml})$ were taken from the field at random on June 15 and were taken from the place within $100 \mathrm{~mm}$ of the root $z$ one, in which lettuce plants sampled on the same day were cultivated, on July 28, August 8, 
12, 22 and 29, and September 5, 12 and 21 by using a cylinder with a radius of $25.2 \mathrm{~mm}$ and a height of $50 \mathrm{~mm}$. Each $10 \mathrm{~g}$ sub-sample was suspended in $50 \mathrm{ml}$ distilled water on a magnetic stirrer for one min.

The original solution and its 10 -fold serial dilutions were dispensed in $0.1 \mathrm{ml}$ aliquots to three plates of PCSM. The plates were incubated at $30^{\circ} \mathrm{C}$ for 4 days, and counted to estimate the population of pathogen. Each experiment had five replicates.

The numbers of lettuce plants with diseased outerleaves were observed on July 28, August 8, 12, 22 and 29, and September 5, 12 and 21. The numbers of lettuce plants with diseased head-leaves were observed on August 22 and 29, and September 5, 12 and 21.

Table 2. Population of Pseudomonas cichorii on lettuce leaves in the leaf test

\begin{tabular}{ccc}
\hline \hline \multirow{2}{*}{$\begin{array}{c}\text { Days after } \\
\text { inoculation }\end{array}$} & \multicolumn{2}{c}{ Colony forming unit/g fresh weight } \\
\cline { 2 - 3 } & $30^{\circ} \mathrm{C}$ & $20^{\circ} \mathrm{C}$ \\
\hline 1 & $6.1 \times 10^{5} \mathrm{~A}^{\mathrm{a})}$ & $7.7 \times 10^{4} \mathrm{~B}$ \\
3 & $8.8 \times 10^{5} \mathrm{~A}$ & $7.3 \times 10^{4} \mathrm{~B}$ \\
7 & $1.3 \times 10^{8} \mathrm{~A}$ & $7.6 \times 10^{4} \mathrm{~B}$ \\
10 & $1.3 \times 10^{8} \mathrm{~A}$ & $9.1 \times 10^{4} \mathrm{~B}$ \\
\hline
\end{tabular}

a) D. M. R. T. $(p=0.05)$.

Table 3. Disease incidence of bacterial rot of lettuce in the leaf test

\begin{tabular}{ccc}
\hline \hline Days after & \multicolumn{2}{c}{ Disease incidence } \\
\cline { 2 - 3 } inoculation & $30^{\circ} \mathrm{C}$ & $20^{\circ} \mathrm{C}$ \\
\hline 1 & 0 & 0 \\
3 & $32.0 \mathrm{~A}^{\mathrm{a})}$ & $4.2 \mathrm{~B}$ \\
7 & $52.2 \mathrm{~A}$ & $7.2 \mathrm{~B}$ \\
10 & $79.6 \mathrm{~A}$ & $8.7 \mathrm{~B}$ \\
\hline
\end{tabular}

a) D. M. R. T. $(p=0.05)$.

\section{RESULTS}

\section{Population of P. cichorii on lettuce leaves in the leaf test}

Population of $P$. cichorii on lettuce leaves, which were incubated at $30^{\circ} \mathrm{C}$, had increased since $3 \mathrm{DAI}$ and was $1.3 \times 10^{8} \mathrm{cfu} / \mathrm{g}$ fresh weight $7 \mathrm{DAI}$ (Table 2). The bacterial population on the leaves, which were incubated at $20^{\circ} \mathrm{C}$, did not increase and had been $7.3 \times 10^{4}$ to $9.1 \times 10^{4}$ $\mathrm{cfu} / \mathrm{g}$ fresh weight.

Disease incidence of bacterial rot of lettuce in the leaf test

When lettuce leaves were incubated at $30^{\circ} \mathrm{C}$, disease incidences 3 and 10 DAI were 32.0 and 79.6, respectively (Table 3). When leaves were incubated at $20^{\circ} \mathrm{C}$, disease incidences was less than ten.

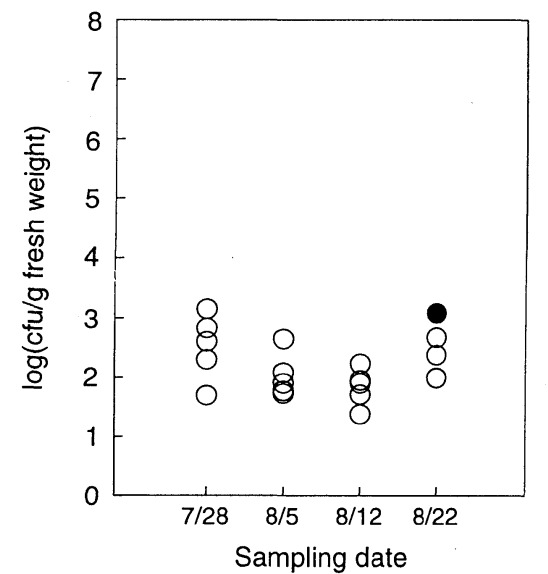

Fig. 3. Populations of Pseudomonas cichorii on lettuce plants before head formation on four sampling dates, where bacterial rot of lettuce was detected $(\bullet)$ and was not detected $(O)$.

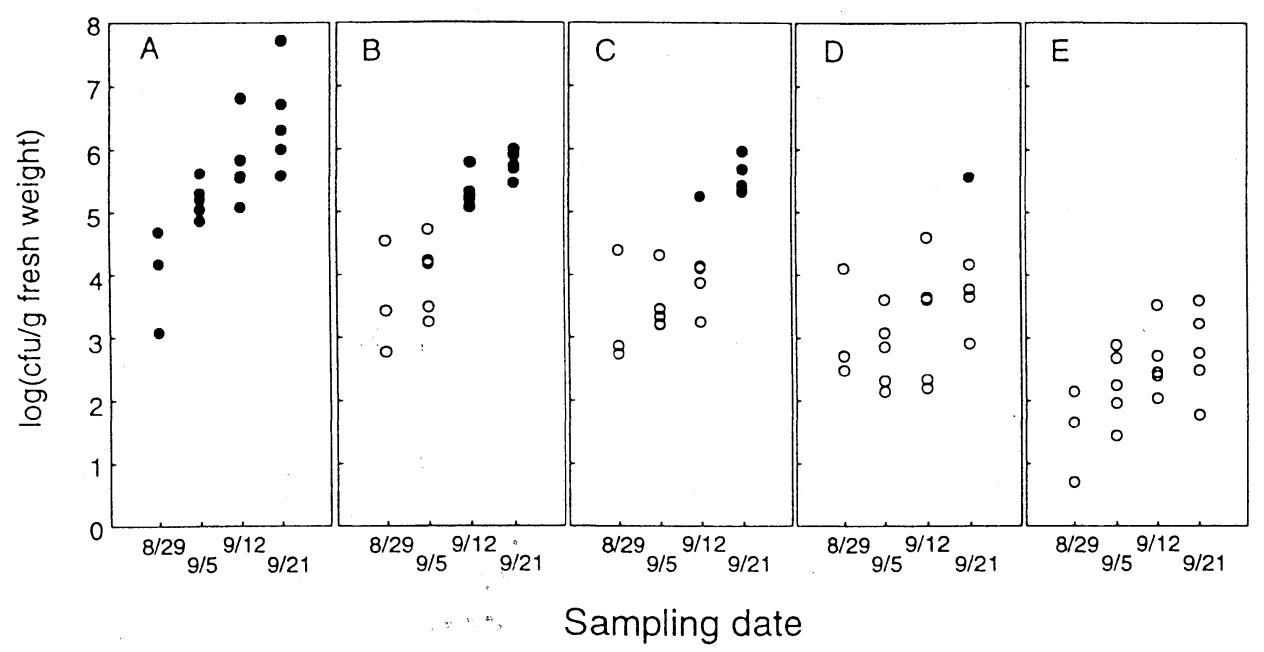

Fig. 4. Populations of Pseudomonas cichorii on lower outer-leaves (A), upper outer-leaves (B), outer head-leaves (C), middle head-leaves (D) and inner head-leaves (E), of lettuce during head formation on four sampling dates, where bacterial rot of lettuce was detected $(\bullet)$ and was not detected $(0)$. 


\section{Population of $P$. cichorii on lettuce in the field}

From July 28 to August $22, P$. cichorii had been isolated at the density of $2.4 \times 10$ to $1.2 \times 10^{3} \mathrm{cfu} / \mathrm{g}$ fresh weight from lettuce plants before head formation (Fig. 3). The bacterial populations on outer-leaves and headleaves increased in the early stage and the middle stage of head formation, respectively. On September $21 P$. cichorii was isolated from lower outer-leaves, upper outer-leaves, outer head-leaves, middle head-leaves and inner head-leaves at the density of $3.8 \times 10^{5}$ to $5.2 \times 10^{7}$, $2.9 \times 10^{5}$ to $1.0 \times 10^{6}, 2.1 \times 10^{5}$ to $9.3 \times 10^{5}, 8.2 \times 10^{2}$ to $3.7 \times$ $10^{5}$ and $6.0 \times 10$ to $4.0 \times 10^{3} \mathrm{cfu} / \mathrm{g}$ fresh weight, respectively (Fig. 4). Bacterial rot was detected on the bulked leaves, from which $P$. cichorii was isolated at the density of above $10^{5} \mathrm{cfu} / \mathrm{g}$ fresh weight.

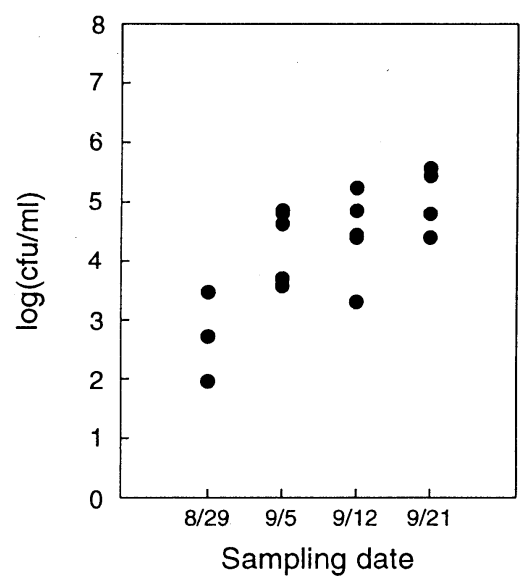

Fig. 5. Populations of Pseudomonas cichorii in dew on outer-leaves of lettuce on four sampling dates.

\section{Population of P. cichorii in dew on outer leaves of lettuce in the field}

Populations of $P$. cichorii in dew on outer-leaves increased during head formation. On September 21, $P$. cichorii was isolated at the density of $2.5 \times 10^{4}$ to $3.6 \times 10^{5}$ $\mathrm{cfu} / \mathrm{ml}$ of dew (Fig. 5).

\section{Population of $P$. cichorii in soil of the field}

From June 15 to September 21, populations of $P$. cichorii in soil had not increased remarkably and had varied among $2.2 \times 10$ and $2.3 \times 10^{3} \mathrm{cfu} / \mathrm{g}$ dry soil (Fig. 6).

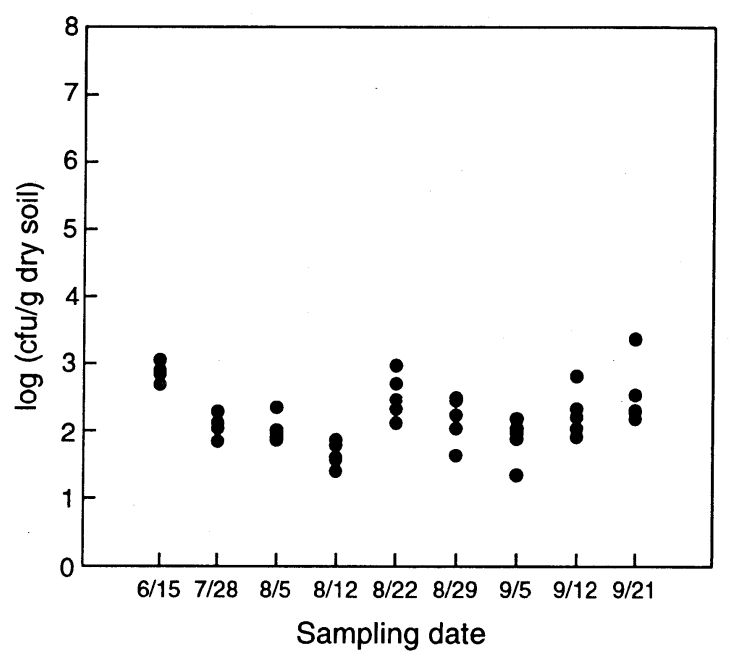

Fig. 6. Populations of Pseudomonas cichorii in soil taken from the place within $100 \mathrm{~mm}$ of the root zone in which lettuce plants sampled on the same day were cultivated. On June 15, soil samples were taken from the field at random.
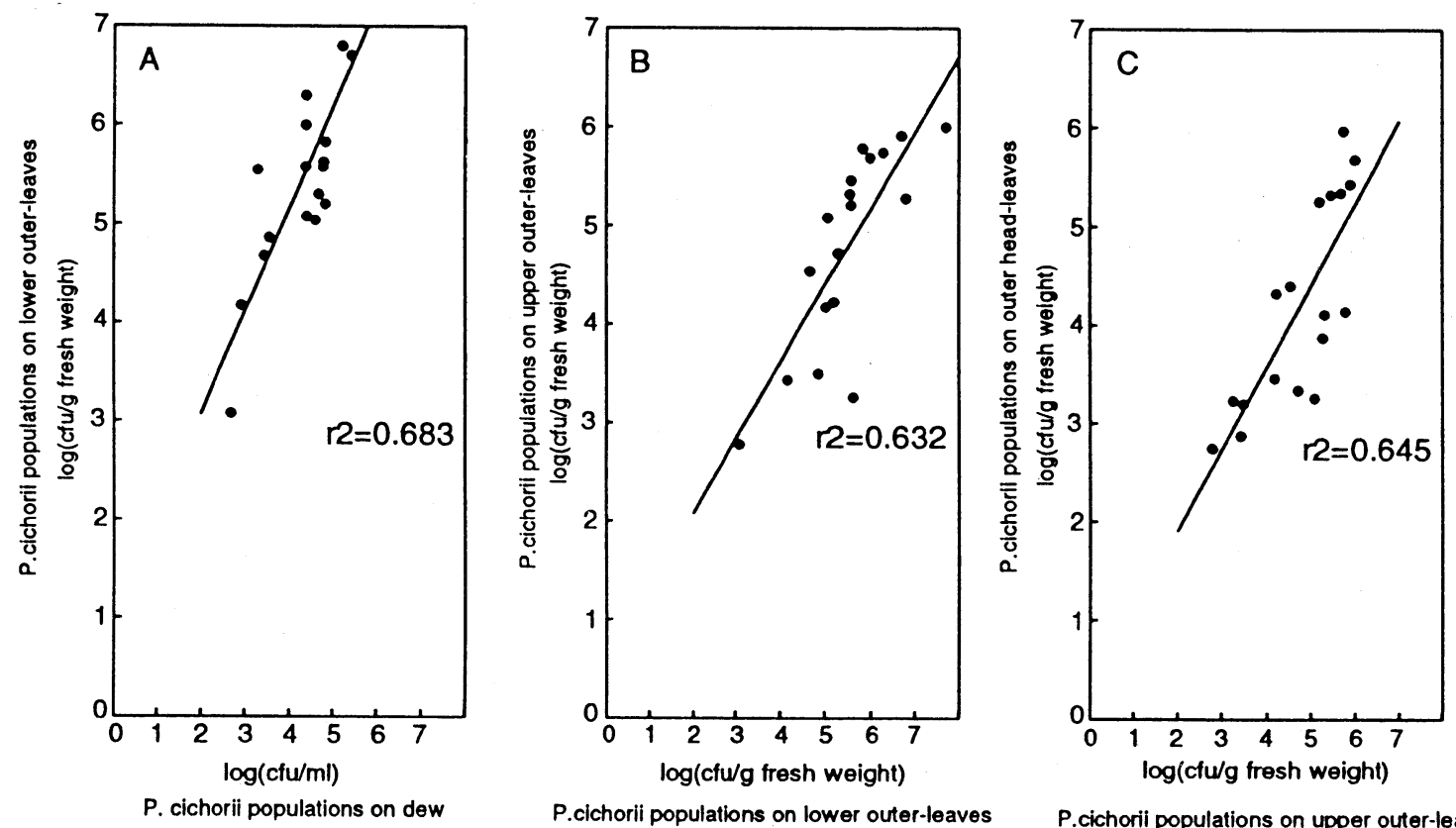

Fig. 7. The positive correlations between logarithmic values of Pseudomonas cichorii populations in dew on outer-leaves and those on lower outer-leaves (A), those on lower outer-leaves and upper outer-leaves (B), and those on upper outer-leaves and outer head-leaves (C). 

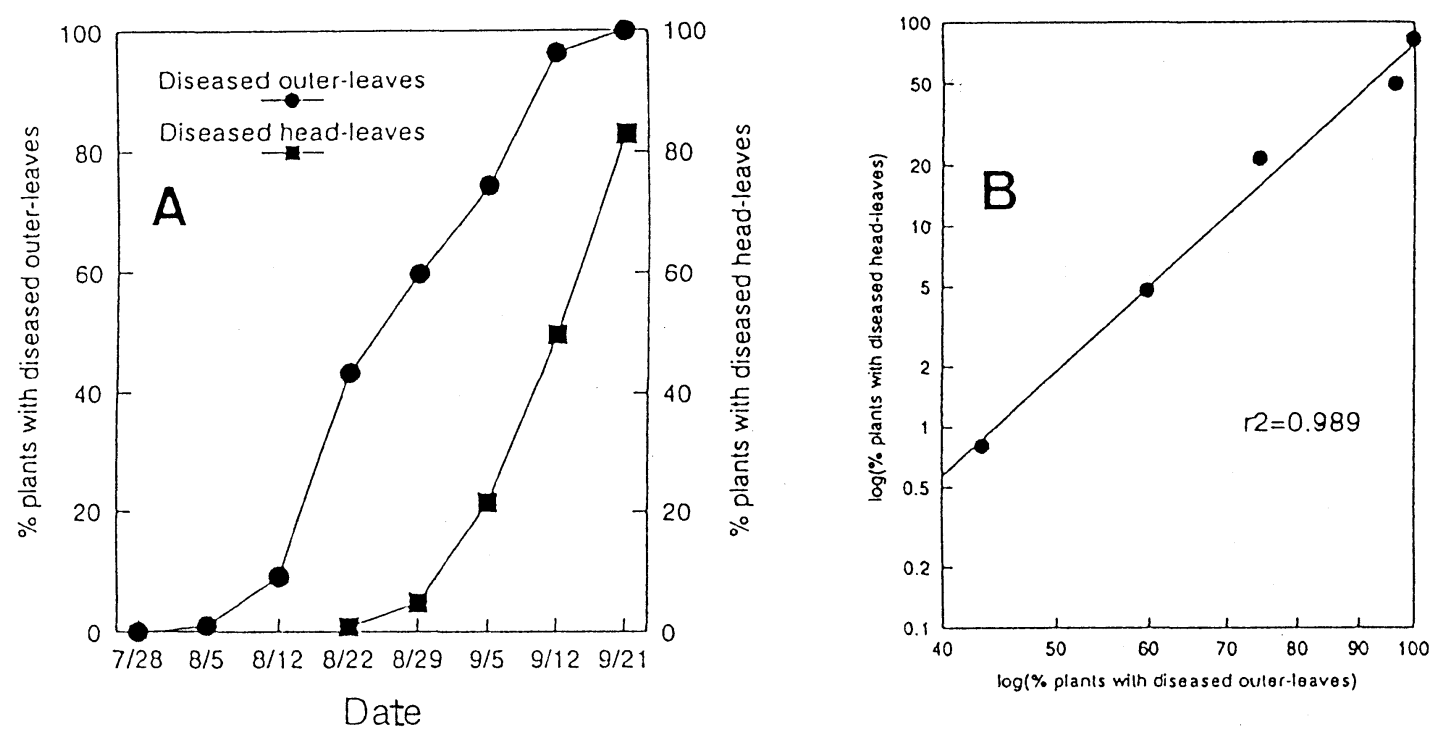

Fig. 8. Disease incidence of bacterial rot of lettuce in the field. (A) The percentages of lettuce plants with outer-leaves diseased by Pseudomonas cichorii and lettuce plants with diseased head-leaves. (B) The positive correlation between logarithmic values of the percentage of lettuce with diseased outer-leaves and those with diseased head-leaves.

\section{Relationships among populations of $P$. cichorii on lettuce leaves}

The logarithmic value of the bacterial population in dew on outer-leaves positively correlated with that on lower outer-leave $\left(r^{2}=0.683\right)$ (Fig. 7-A). The logarithmic values of the bacterial populations on lower outer-leaves and upper outer-leaves $\left(r^{2}=0.632\right)$ and those on upper outer-leaves and outer head-leaves $\left(r^{2}=0.645\right)$ also showed positive correlation (Fig. 7-B and C).

Disease incidence of bacterial rot of lettuce in the field

Bacterial rot, which had been first detected on outerleaves, was detected on outer head-leaves and continuously progressed into middle head-leaves contacted with diseased outer head-leaves (Fig. 1).

The percentages of lettuce plants with diseased outerleaves on July 28 and August 5 were zero and one, respectively (Fig. 8-A). On and after August 12, the number of lettuce plants with diseased outer-leaves increased remarkably, and the percentage of lettuce plants with diseased outer-leaves on September 21 was 100. The number of lettuce plants with diseased headleaves increased on and after the middle stage of head formation, and the percentages of lettuce plants with diseased head-leaves on August 29 and September 21 were 4.8 and 82.9 , respectively.

The logarithmic value of percentage of lettuce plants with diseased head-leaves positively correlated with that of lettuce plants with diseased outer-leaves $\left(r^{2}=0.989\right)$ (Fig. 8-B).

\section{DISCUSSION}

Hirano et $a l_{.}{ }^{3-5)}$ have reported that the epiphytic bacterial population sizes are usually lognormally dis- tributed, and that knowledge of the probability distribution of epiphytic bacterial populations on individual leaves provides a useful tool toward understanding the quantitative relationship between epiphytic pathogen population size and foliar disease caused by these phytopathogenic bacteria. Lindemann et $a l^{6}{ }^{6}$ have reported that disease incidence of brown spot of bean can be predicted by the frequency with which populations of $P$. syringae pv. syringae exceed approximately $10^{4} \mathrm{cfu} / \mathrm{g}$ fresh weight on symptomless leaflets of bean. In the leaf test, population of $P$. cichorii on the lettuce leaves incubated at $20^{\circ} \mathrm{C}$ did not increase up above $10^{5}$ $\mathrm{cfu} / \mathrm{g}$ fresh weight, and disease incidence of bacterial rot of lettuce was less than ten. In the field test, when population of $P$. cichorii on lettuce leaves during head formation was plotted on the cumulative probability scale, they seemed to assume a lognormal distribution (data not shown). Bacterial rot was detected on the bulked leaves, from which $P$. cichorii was isolated at the density of above $10^{5} \mathrm{cfu} / \mathrm{g}$ fresh weight. These results suggested that $P$. cichorii existed on leaves of lettuce during head formation as the epiphytic bacterium, and the disease incidence on lettuce leaves depended on $P$. cichorii populations on the leaves.

Results of relationship among populations of $P$. cichorii on lettuce leaves suggested that $P$. cichorii, with which outer-leaves had been infected, was an important infection source of the disease on head-leaves. Therefore, behavior of $P$. cichorii on lettuce is revealed to be as follows. $P$. cichorii, with which outer-leaves have been infected through dew, removes into outer headleaves contacted with outer-leaves and multiplies on outer head-leaves, resulting in bacterial rot. Middle head-leaves underneath diseased outer head-leaves are continuously infected with the bacteria. 
The primary infection sources of the disease seem to be seeds, infected lettuce debris, weeds and soil ${ }^{1,2,9,12-14)}$. In this study, $P$. cichorii was isolated from soil before transplanting. However, the bacterial population in soil was less than $10^{3} \mathrm{cfu} / \mathrm{g}$ dry soil that Uematsu et al. ${ }^{14)}$ reported as the minimum detectable limits and did not correlate with the bacterial population on lettuce leaves and disease incidence of bacterial rot of lettuce. In this field many lettuce plants have been severely infected with $P$. cichorii at any year, and Chinese cabbage was cultivated the year before. Tsuchiya et $a l .{ }^{12)}$ has reported that eighty-three crops containing Chinese cabbage are infected with $P$. cichorii. It was suggested that $P$. cichorii, which had survived in soil or in infected plant debris during overwintering was thought to be one of the primary infection sources of the disease.

We wish to thank Mr. T. Shirakawa, Morioka Branch, National Research Institute of Vegetables, Ornamental plants and Tea, for his providing the bacterial strain, and Mr. K. Sakuyama and Mr. T. Sato, Highland Cool-zone Development Center, Iwate Horticultural Experiment Station, for their technical suggestions.

\section{Literature cited}

1. Bazzi, C., Piazza, C. and Mazzucchi, U. (1984). Survival in the field of Pseudomonas cichorii (Swingle) Stapp, causal agent of lettuce varnish spot. Phytopathol. Z. $111: 251-258$.

2. Grogan, R.G., Misaghi, I.J., Kimble, K.A., Greeathead, A.S., Ririe, D. and Bardin, R. (1977). Varnish spot, destructive disease of lettuce in California caused by Pseudomonas cichorii. Phytopathology 67 : 957-960.

3. Hirano, S.S., Nordheim, E.V., Arny, D.C. and Upper, C.D. (1982). Lognormal distribution of epiphytic bacterial populations on leaf surfaces. Appl. Environ. Microbiol. $44: 695^{-700 \text {. }}$

4. Hirano, S.S. and Upper, C.D. (1983). Ecology and epidemiology of foliar bacterial plant pathogen. Annu. Rev. Phytopathol. 21 : 243-269.

5. Hirano, S.S. and Upper, C.D. (1990). Population biology and epidemiology of Pseudomonas syringae. Annu. Rev. Phytopathol. 28 : 155-177.

6. Lindemann, J., Arny, D.C. and Upper, C.D. (1984). Use of an apparent infection threshold population of Pseudomonas syringae to predict incidence and severity of brown spot of bean. Phytopathology $74: 1334-1339$.

7. Nakatani, F. and Hiraragi, T. (1988). Occurrence of lettuce diseases in the open field. Annu. Rept. Plant Prot. North Japan 39 : 121-124.

8. Ohata, K., Tsuchiya, Y. and Shirata, A. (1979). Difference in kinds of pathogenic bacteria causing head rot of lettuce of different cropping types. Ann. Phytopathol. Soc. Jpn. 45 : 333-338.

9. Ohata, K., Serizawa, S. and Shirata, A. (1982). Infection source of the bacterial rot of lettuce caused by Pseudomonas cichorii. Bull. Natl. Inst. Agric. Sci. C 36 : 75-80.

10. Sekiguchi, A. and Suyama, K. (1982). Studies on the bacterial rot of lettuce caused by Pseudomonas cichorii (Swingie 1925) Stapp 1928. Bull. Nagano Veg. Ornam. Crops Exp. Sta. 2 : 1-62.

11. Tsuchiya, Y., Ohata, K., Iemura, H., Sanematsu, T., Shirata, A. and Fujii, H. (1979). Identification of causal bacteria of head rot of lettuce. Bull. Natl. Inst. Agric. Sci. C $33: 77-99$.

12. Tsuchiya, Y., Ohata, K. and Shirata, A. (1980). Pathogenicity of the causal bacteria of head rot of lettuce, Pseudomonas cichorii, P. marginalis and P. viridiflava, to various crop plants. Bull. Natl. Inst. Agric. Sci. C 34 : $51-73$.

13. Tsuchiya, Y., Ohata, K. and Azegami, K. (1982). Pathogenicity of the causal bacteria of rot of lettuce, Pseudomonas cichorii, PS. marginalis pv. marginalis and Ps. viridiflava to various weeds. Bull. Natl. Inst. Agric. Sci. C $36: 41-59$.

14. Uematsu, T., Takatsu, A. and Ohata, K. (1982). A medium for the selective isolation of Pseudomonas cichorii. Ann. Phytopathol. Soc. Jpn. 48 : 425-432.

\section{和 文 摘 要}

曳地康史・斉藤 光・鈴木一実：レタスに生存する Pseudomonas cichorii 菌数の推移とレタス腐敗病発病との関係

ポット栽培したレタス (Lactuca sativa L. 品種サクセス) の 第 7 葉をPseudomonas cichorii 菌液中に浸漬した。高湿度 $30^{\circ} \mathrm{C}$ 条件下で 7 日間静置培養したところ, レタス腐敗病の激しい発 病が認められ, レタス葉に生存する P. cichorii 菌数は $1.3 \times 10^{8}$ $\mathrm{cfu} / \mathrm{g}$ となった。 $20^{\circ} \mathrm{C}$ で静置培養した場合, レタス腐敗病の発 病は顕著に軽く, レタス葉に生存する P. cichorii 菌数は $10^{5}$ $\mathrm{cfu} / \mathrm{g}$ 以下となった。例年, 腐敗病が多発する固場において栽培 されているレタスに生存するP. cichorii 菌数の推移と腐敗病発 病との関係について検討した。土㙵に生存する P. cichorii 菌数 は，定植 37 日前から収穫時まで $10^{4} \mathrm{cfu} / \mathrm{g}$ dry soil 以下であっ た。結球前のレタス体に生存するP. cichorii 菌数は $10^{4} \mathrm{cfu} / \mathrm{g}$ 以下であった。結球期のレタス葉に生存する P. cichorii 菌数は 対数正規分布を示し, P. cichorii 菌数が $10^{5} \mathrm{cfu} / \mathrm{g}$ 以上を示すレ 夕ス葉で腐敗病の発病が認められた。外葉と結球葉に生存する P. cichorii 菌数には正の相関が認められ, それぞれ結球初期と 中期以降に増加した。また, 外葉の発病株率と結球葉の発病株率 にも高い正の相関が認められた。すなわち，P. cichorii は結球 期のレタス葉において葉面微生物として生存しており, 菌量が $10^{5} \mathrm{cfu} / \mathrm{g}$ 以上となった場合にレタスに病徵が生じ, 外葉に感染 した P. cichorii が結球葉における発病の伝染源となる。 